\title{
Pemikiran Ibnu Hajar Al-Asqalani dalam Ilmu Administrasi Negara
}

\author{
${ }^{1}$ Wisber Wiryanto \\ ${ }^{1}$ Lembaga Administrasi Negara, Indonesia; wisberwiryanto@yahoo.com
}

\begin{abstract}
Ibn Hajar Al-Asqalani (773-852 H) was a classical Islamic scholar and an author of the Fathul Baari book which explains the Sahih Bukhari book. His book contains themes that discuss among others law in the maintenance of power and government in the State which is thought to have a connection with public administration sciences. Therefore, research about Ibn Hajar Al-Asqalani's thoughts in the public administration sciences was conducted, with a problem formulation, how the concept of Ibn Hajar al-Asqalani's thoughts in public administration sciences? The purpose of this study to know about Ibn Hajar Al-Asqalani's thoughts in public administration sciences from Fathul Baari books. Library research methods are used to study the Fathul Baari books as a source of data/subject of research; then as the focus/object of research is public administration sciences. The data collected were processed and analyzed using induction and deduction techniques. The research was conducted in the first semester of 2020. The results of the study found a concept from Ibn Hajar Al-Asqalani's thoughts in public administration sciences, which includes categories: leadership; government officials; personnel in the organization; governance; administrative principles; salary, and reward \& punishment which is relevant to public administration sciences which are sourced from the Qur'an, hadith, and Islamic legacy. Next, stakeholders and related academics need to use these findings for educational, research, and development purposes public administration sciences using nonWestern perspectives.
\end{abstract}

Keywords: Fathul Baari, Ibn Hajar Al-Asqalani, Public Administration Sciences, Islamic Thought

\section{Pendahuluan}

Ibnu Hajar Al-Asqalani (773-852 H.) ialah tokoh sarjana Islam zaman klasik pengarang kitab Fathul Baari penjelasan kitab Shahih Bukhari yang berisi tema iman, ilmu dan amal. Penjelasan kitab tersebut dilakukan dengan cara menambah keterangan hadits, ijtihad-nya dan pelajaran yang dapat diambil. Tema tersebut mempunyai hubungan relevansi dengan persoalan di bidang hukum dan penyelenggaraan kekuasaan pemerintahan negara. Selanjutnya, persoalan tersebut mempunyai hubungan relevansi dengan ilmu administrasi negara. Hal tersebut dapat dilihat eksistensinya, adanya mata kuliah ilmu hukum administrasi negara dalam silabus ilmu administrasi negara di perguruan tinggi; dan adanya persoalan penyelenggaraan kekuasaan pemerintahan negara yang mempunyai hubungan relevansi dengan ilmu administrasi negara.

Diantara perguruan tinggi ada yang menghadapi permasalahan kelangkaan referensi tentang pemikiran tokoh Islam dalam ilmu administrasi negara. Padahal banyak tokoh sarjana Islam pada zaman klasik yang menghasilkan kitab-kitab yang menjelaskan tentang ilmu-ilmu keislaman dan ilmu pengetahuan yang mempunyai relevansi dengan ilmu pengetahuan kontemporer. 
Oleh karena itu, perlu dilakukan upaya mendorong penelitian dan penulisan tentang pemikiran tokoh sarjana Islam zaman klasik dalam ilmu administrasi negara sehingga kebutuhan mahasiswa akan referensi tersebut dapat dipenuhi. Adapun penelitian ini diharapkan dapat memberikan kontribusi referensi dan memberikan manfaat bagi perkembangan studi ilmu administrasi negara dengan pendekatan non-western perspective.

Perkembangan studi ilmu administrasi negara dengan pendekatan tersebut, ditandai dengan telah diselenggarakannya konferensi internasional the-Asian Association for Public Administration (AAPA) di Universitas Gajah Mada, Yogyakarta, tanggal 22-23 Maret 2018. Tema utamanya "Reinventing Public Administration in a Globalized World: A Non-Western Perspective", yang diikuti oleh ratusan peserta dan presenter dari kalangan perguruan tinggi negeri dan swasta serta instansi pemerintah dari berbagai negara. Penulis dalam konferensi tersebut mempresentasikan makalah berjudul "Developing Theories of Non-Western Public Administration Through the Islamization of Public Administration” (AAPA, 2018).

Berdasarkan penelusuran hasil penelitian yang relevan dengan penelitian ini maka ditemukan berbagai artikel yang ditulis oleh kalangan akademisi dari berbagai disiplin ilmu pengetahuan, sebagai berikut: (1) Ilmu Pendidikan Islam: (a) Ibnu Awwaliansyah (2017) Tesis: Pemikiran Pendidikan Ibnu Hajar Al-Asqalani dan implementasinya, Jakarta: Institut Ilmu AlQur'an, Jakarta; (b) Minggusta Juliadarma (2019) Konsep Pendidikan Islam dalam Kitab Fathul Baari, el-Bidayah: Journal of Islamic Elementary Education, Maret, 2019; (c) Siti Khotijah (2019) Konsep Pendidikan Jihad Menurut Ibnu Hajar Al-Asqalani dalam kitab Fathul Baari, Lampung: UIN Raden Intan; (2) Ilmu Ekonomi: Mijal Fauzi (2016) Ilmu Ekonomi: Hukum Makelar menurut tinjauan hadits Ibnu Hajar Al-Asqalani (Studi Kitab Fathul Baari), Melaboh: STAIN Tengku Dirundeng; dan

Selanjutnya, (3) Ilmu Administrasi Negara: (a) Haroon Khan Sherwani (1964), Buku kumpulan artikel, berjudul "mempelajari pendapat sarjana-sarjana Islam dalam ilmu administrasi Negara" yang terdiri dari Ibnu Abir Rabi', Al-Farabi, Imam Mawardi dan Kaikaus; Nizamul Muluk At-Tusy, Imam Al-Ghazali, Ibnu Khaldun, Mahmud Gawan dan Said Ahmad Khan; dan (b) Universitas Dhaka, Fakultas Administrasi Negara (tanpa tahun), dalam publikasi berjudul Contribution of Kautilya, Confucius, Ibn Khaldun and Max Weber on State Administration and Governance: relevance and Contrast with the modern concepts.

Jadi, penelitian yang relevan dengan penelitian ini telah dilakukan dalam lapangan ilmu pendidikan Islam, ilmu ekonomi dan ilmu administrasi negara. Namun, belum ada penelitian tentang pemikiran Ibnu Hajar Al-Asqalani dalam ilmu administrasi negara. Oleh karena itu, penelitian tentang pemikiran Ibnu Hajar Al-Asqalani dalam ilmu administrasi negara bersifat baru (novelty) sehingga diharapkan dapat memberikan kontribusi referensi yang bermanfaat bagi perkembangan studi ilmu administrasi negara dengan pendekatan non-western perspective.

Penelitian ini diawali dengan melakukan tinjauan pustaka sejumlah buku ilmu administrasi negara yang ditulis oleh pakar administrasi negara kontemporer, antara lain: Dwight Waldo; Max Weber; Luther Gullick dan Lyndall Urwick. Mereka menjelaskan tentang definisi konseptual administrasi negara. Dwight Waldo (1955) dalam bukunya The Study of Public Administration, menjelaskan definisi administrasi negara, yaitu: (1) Public administration is the organization and management of men and materials to achieve the purposes of government; (2) Public administration is the art and science of management as applied to affairs of state. 
Berdasarkan definisi tersebut, maka kategori administrasi negara meliputi organisasi, manajemen, personil, peralatan, urusan negara, dan tujuan pemerintah. Dalam hal ini, administrasi negara dapat diamati lokus dan fokusnya. Fokusnya adalah urusan pelaksanaan kebijakan untuk mencapai tujuan pemerintahan negara; sedangkan lokusnya adalah organisasi atau birokrasi penyelenggara kekuasaan pemerintahan negara.

Max Weber menguraikan konstruksi tipe ideal birokrasi, dalam buku The Theory of Social and Economic Organization (Parsons, 1947), meliputi: (1) clearly defined sphere of competence, subject to impersonal rules; (2) a regular system of appointment and promotion on the basis of free contract; and (3) technical training as a regular requirement and fixed salaries paid in money. Berdasarkan konsep tersebut, dapat diuraikan kategori-kategori administrasi Negara meliputi kompetensi, aturan impersonal, promosi, kontrak kerja, pelatihan, dan gaji.

Gullick and Urwick (1937) menguraikan prinsip administrasi dalam Papers on the Science of Administration, meliputi POSDCORB. POSDCORB is an acronym that represents the seven main functions of an executive in an organization: planning, organizing, staffing, directing, coordinating, reporting, and budgeting. Jadi, kategori administrasi Negara meliputi prinsip administrasi atau fungsi-fungsi manajemen publik yang meliputi POSDCORB, manajemen, personil, peralatan, kompetensi, aturan impersonal, promosi, kontrak kerja, pelatihan, dan gaji, urusan dan tujuan pemerintahan Negara.

Selanjutnya, melakukan penelitian hubungan kategori-kategori dari buku administrasi negara kontemporer tersebut, dengan kategori-kategori dari kitab Fathul Baari yang ditulis oleh oleh Ibnu Hajar Al-Asqalani tahun 817-824 Hijriah, dengan asumsi adanya pemikiran Ibnu Hajar Al-Asqalani dalam ilmu Administrasi negara dan relevansinya pada masa kini.

Kitab Fathul Baari dijadikan sebagai sumber data penelitian, dengan alasan. Pertama, kitab Fathul Baari membahas tema iman, ilmu dan amal yang dijelaskan dengan memberikan keterangan hadits, ijtihad-nya dan pelajaran yang dapat diambil. Tema tersebut, berhubungan dengan persoalan hukum dan penyelenggaraan kekuasaan pemerintahan negara termasuk ilmu administrasi negara yang dikenal sebagai sebuah disiplin ilmu kontemporer. Kitab tersebut merupakan sebuah karya monumental yang digunakan sebagai referensi ilmu pengetahuan sampai sekarang. Di Indonesia, kitab tersebut telah diterjemahkan kedalam bahasa Indonesia dengan judul Fathul Baari penjelasan kitab Shahih al-Bukhari. Satu set kitab tersebut terdiri dari 36 jilid buku tebal, terbitan Pustaka Azzam, Jakarta, tahun 2012.

Kedua, Ibnu Hajar Al-Asqalani ialah tokoh pemikir sarjana Islam yang sangat produktif menghasilkan kitab-kitab ilmu dalam berbagai bidang (cabang disiplin ilmu naqli dan aqli) yang hingga sekarang telah tersebar ke seluruh penjuru. Ibnu Hajar Al-Asqalani bernama lengkap Ahmad bin Ali bin Muhammad bin Muhammad bin Ali bin Mahmud bin Ahmad bin Hajar Al Kinani Al Asqalani lahir di Mesir tahun 773 Hijriah.

Perkembangan kehidupan dan karirnya dapat dikelompokkan kedalam dua periode yaitu periode belajar dan menuntut ilmu; dan periode bekerja dan mengamalkan ilmu. Periode belajar dan menuntut ilmu: Ibnu Hajar Al-Asqalani banyak melakukan perjalanan ke berbagai penjuru untuk mencari ilmu dan berguru kepada para ulama dan ahli ilmu pengetahuan. Ibnu Khaldun ialah salah seorang guru dari Ibnu Hajar Al-Asqalani (Ibnu Khaldun, 2014 dan Sherwani, 1964) tokoh sarjana Islam zaman klasik (732-808 H.) yang telah menulis berbagai kitab baik tentang ilmu-ilmu keislaman, seperti ilmu hadits, figh, ushul fiqh; maupun tentang ilmu pengetahuan, filsafat, sejarah, ekonomi, sosial dan politik. Salah satu kitabnya yang fenomenal berjudul Mukaddimah. 
Periode bekerja dan mengamalkan ilmu: Dalam pemerintahan beliau memegang jabatan tertinggi sebagai hakim agung (Qadhi Qudhat); dan ulama besar Islam; dan sebagai tenaga pengajar. Beliau menguasai ilmu nahwu dan memiliki kemampuan untuk memecahkan persoalan dengan mengambil syahid (contoh) dari Al-Qur'an dan hadits. Beliau seorang faqih (ahli fikih) dan Muhaddits (ahli hadits), dengan metodenya digabungkan antara fikih dan hadits; dan memiliki kemampuan istinbath (mengambil kesimpulan hukum) dari nash atau kemampuan dalam menggabung beberapa pendapat sehingga beliau termasuk muhaddits al fuqaha dan faqih al-Muhadditsin.

Beliau sangat produktif menghasilkan kitab-kitab ilmu dalam berbagai bidang (cabang disiplin ilmu naqli dan aqli) antara lain: (1) aqidah; (2) ilmu al-Quran; (3) ilmu hadits; (4) sejarah; dan (5) bahasa arab. Kitab-kitab hasil karya beliau telah tersebar di seluruh penjuru. Salah satu kitabnya yang fenomenal berjudul Fathul Baari, dijadikan sebagai sumber data penelitian ini. Muridnya berdatangan dari seluruh penjuru, diantaranya: (1) Al Hafizh AsSakhawi (831-902 H.) seorang ulama besar, ahli hadits, tafsir, fikih, ilmu bahasa dan sastra Arab, dan sejarah; dan (2) Zakaria Al Anshari (826-926 H.) Syaikh Islam, Hakim Agung, ahli tafsir, fikih, qira'at, tasawuf, nahwu dan mantiq, dan penghafal hadits. Beliau wafat di Mesir tahun 852 Hijriah.

Sehubungan dengan latar belakang permasalahan tersebut, maka dipandang perlu (urgent) melakukan penelitian pemikiran Ibnu Hajar Al-Asqalani dengan mengambil fokus ilmu administrasi negara sebagai obyek penelitian; dan kitab Fathul Baari sebagai subyek atau sumber data penelitian. Tujuan penelitian untuk menganalisis konsep pemikiran Ibnu Hajar AlAsqalani dalam ilmu administrasi negara dan relevansinya pada masa kini. Dengan rumusan permasalahan, bagaimana pemikiran Ibnu Hajar Al-Asqalani dalam ilmu administrasi negara.

\section{Metode Penelitian}

Metode penelitian studi pustaka digunakan untuk meneliti pemikiran Ibnu Hajar AlAsqalani dalam ilmu administrasi negara. Penelitian ini mengambil fokus ilmu administrasi negara sebagai obyek penelitian; dan kitab Fathul Baari sebagai subyek dan sumber data penelitian. Pengumpulan data dilakukan dengan teknik deduktif-induktif untuk mengetahui konsep pemikiran Ibnu Hajar Al-Asqalani di kitab Fathul Baari dalam persoalan hukum dan penyelenggaraan kekuasaaan pemerintahan negara yang mempunyai hubungan relevansi dengan ilmu administrasi negara.

Kriteria yang digunakan dalam pengumpulan data penelitian ini adalah keterangan berupa konsep dan kategori dalam persoalan hukum dan penyelenggaraan kekuasaaan pemerintahan negara yang yang mempunyai hubungan relevansi dengan ilmu administrasi negara. Selanjutnya, dilakukan analisis sintesis terhadap data yang dikumpulkan untuk menarik kesimpulan.

\section{Hasil dan Pembahasan}

Hasil pengumpulan data yang bersumber dari kitab Fathul Baari berdasarkan teknik deduksi-induksi maka diketahui pemikiran Ibnu Hajar Al-Asqalani mempunyai hubungan relevansi dengan disiplin ilmu administrasi negara dalam 17 (tujuh belas) kategori. 


\section{Pemimpin Akan Dimintai Pertanggungjawaban}

Al-Asqalani (2012) menjelaskan konsep pemimpin berdasarkan firman Allah, yang artinya, "Taatilah Allah dan taatilah Rasul (Nya) serta ulil amri diantara kamu." (Qs. AnNissa' [4]: 59). Selanjutnya berdasarkan hadits, Rasulullah SAW bersabda "Ketahuilah setiap kalian adalah pemimpin, dan setiap kalian akan dimintai pertanggungjawaban atas yang dipimpinnya. Imam adalah pemimpin atas manusia dan dia dimintai pertanggungjawaban atas yang dipimpinnya. Seorang laki-laki adalah pemimpin atas penghuni rumahnya dan dia akan dimintai pertanggungjawaban atas yang dipimpinnya. Seorang perempuan adalah pemimpin atas penghuni rumah suaminya serta anak suaminya dan dia akan dimintai pertanggungjawaban tentang mereka. Budak seseorang adalah pemelihara harta majikannya dan dia akan dimintai pertanggung jawaban tentang itu. Ketahuilah sungguh kamu semua adalah pemimpin dan kamu semua akan dimintai pertanggungjawaban atas yang dipimpinnya".

Keterangan hadits: (Bab firman Allah, Taatilah Allah dan taatilah Rasul serta ulil amri di antara kamu). Menurut Al-Asqalani (2012), disini terdapat isyarat tentang keunggulan pendapat yang mengatakan bahwa ayat ini turun berkenaan dengan ketaatan terhadap para pemimpin atau pemerintah. Berkenaan dengan adanya konsep ketaatan terhadap pemerintah tersebut maka konsep pemikirannya akan berhubungan dengan ilmu administrasi Negara.

Selanjutnya, menurut Al-Asqalani (2012), Al Khaththabi berkata, mereka bersekutu yakni pemimpin dan seorang laki-laki serta semua yang disebutkan dalam hadits dalam sifat pemimpin namun dengan makna berbeda-beda. Kepemimpinan (pemerintah) penguasa tertinggi adalah menjaga syariat dengan menegakkan hukum serta berlaku adil dalam menetapkan hukum. Kepemimpinan seorang laki-laki terhadap keluarganya adalah cara mengurusi dan memberikan hak-hak mereka. Kepemimpinan seorang perempuan adalah mengatur urusan rumah, anak-anak, pembantu dan memberi nasehat serta masukan kepada suami dalam semua itu. Sedangkan kepemimpinan pembantu adalah memelihara apa yang ada dalam tanggungjawabnya serta melakukan apa yang dapat mendatang kebaikan padanya.

Jadi, semua manusia adalah pemimpin dan akan dimintai pertanggungjawaban atas yang dipimpinnya. Dalam penyelenggaraan pemerintahan terdapat jabatan pimpinan. Kepemimpinan penguasa tertinggi adalah menjaga syariat dengan menegakkan hukum serta berlaku adil dalam menetapkan hukum dan akan dimintai pertanggungjawaban.

\section{Mendengar Dan Taat Kepada Imam Selama Tidak Dalam Kemaksiatan}

Rasulullah bersabda "Mendengar dan taat kepada seorang (pemimpin) muslim berlaku dalam hal yang disukai dan tidak disukai, selama pemimpin itu tidak menyuruh melakukan kemaksiatan. Apabila dia menyuruh melakukan kemaksiatan maka tidak boleh didengar dan ditaati”. (HR. Bukhari). Keterangan hadits menurut Al-Asqalani (2012), bahwa Imam Bukhari mengaitkannya dengan kata 'imam" (pemimpin tertinggi) meski dalam hadits tadi terdapat perintah taat untuk setiap pemimpin walau bukan imam, karena letak perintah taat kepada pemimpin adalah hendaknya perintah itu datang dari imam. Jadi, perintah mendengar dan taat kepada pemimpin dalam penyelenggaraan pemerintahan berlaku dalam hal yang disukai dan tidak disukai, apabila menyuruh melakukan kemaksiatan maka tidak boleh didengar dan diikuti. 


\section{Orang Atau Pemimpin Yang Suka Mempersulit Maka Allah Akan Mempersulitnya}

Barangsiapa menginginkan popularitas diantara manusia dibalik perbuatannya, maka Allah akan menampakkan aibnya pada hari Kiamat - beliau bersabda pula - Dan barang siapa mempersulit maka Allah akan mempersulit dirinya pada Hari Kiamat'. Sabda Nabi SAW dalam hadits Aisyah yang diriwayatkan Imam Muslim, "Ya Allah barangsiapa memegang urusan umatku lalu dia mempersulit mereka maka persulitlah dirinya”.

Keterangan hadits menurut Al-Asqalani (2012) maksudnya termasuk balasan yang sepadan dengan perbuatan. Dalam makna menimbulkan mudharat, pemimpin membawa manusia kepada perkara yang menyusahkan rakyat. Jadi, pemimpin yang suka mempersulit urusan sehingga menyusahkan rakyatnya, maka Allah akan mempersulit pemimpin itu, sebagai balasan yang sepadan dengan perbuatannya.

\section{Imam Atau Pemimpin Memeriksa Para Pembantunya}

Dari Abu Humaid As-Sa'idi, bahwa Nabi SAW pernah mempekerjakan Ibnu AlUtabiyyah untuk mengurus sedekah bani Sulaim. Ketika datang kepada Rasulullah SAW dan diperiksa maka dia berkata, Ini untuk kamu dan ini hadiah yang diberikan kepadaku. "Ini untuk kamu dan ini hadiah yang diberikan kepadaku. Rasulullah SAW bersabda, "Mengapa engkau tidak duduk di rumah bapakmu dan rumah ibumu, hingga hadiahmu datang kepadamu, sekiranya engkau memang orang benar."

Kemudian Rasulullah SAW berdiri dan berkhutbah di hadapan orang-orang. Beliau memuji Allah yang menyanjung-Nya, setelah itu, beliau bersabda, "Amma ba'du sungguh aku telah mempekerjakan beberapa orang laki-laki di antara kalian untuk suatu urusan yang dikuasakan Allah kepadaku, lalu ada salah seorang dari kalian datang dan berkata, 'Ini untuk kamu dan ini adalah hadiah yang diberikan kepadaku. Mengapa dia tidak duduk di rumah bapaknya dan ibunya hingga hadiah datang kepadanya jika dia memang orang yang benar. Demi Allah, tidaklah salah seorang kalian mengambil sesuatu darinya-Hisyam berkata-tanpa haknya, melainkan dia datang kepada Allah sambil membawanya pada hari Kiamat." (AlAsqalani, 2012). Jadi, pemimpin dalam penyelenggaraan pemerintahan menjalankan fungsi pengawasan yang dilakukan dengan mengadakan pemeriksaan (auditing) terhadap pegawai yang membantunya.

\section{Jabatan Adalah Amanah}

Orang yang tidak meminta jabatan akan ditolong oleh Allah; sedangkan orang yang meminta jabatan tidak akan ditolong oleh Allah. Dari Abdurrahman bin Samurah, dia berkata, "Nabi SAW bersabda kepadaku, Wahai Abdurrahman, jangan engkau minta jabatan, karena sesungguhnya jika engkau diberi jabatan dengan jalan memintanya maka engkau dibuat susah dengannya, dan jika engkau diberi tanpa memintanya maka engkau akan ditolong untuk melaksanakannya."

Keterangan hadits menurut Al-Asqalani (2012), barangsiapa meminta jabatan lalu diberikan maka dia tidak akan ditolong karena ambisinya itu. Dapat disimpulkan, meminta sesuatu yang berkenaan dengan jabatan adalah makruh (tidak disukai). Maksud dalam jabatan ini adalah pemerintahan, pengadilan, keuangan, dan lainnya. Barangsiapa berambisi mendapatkan yang demikian maka dia tidak akan diberi pertolongan. 
Namun, hal ini bertentangan dengan riwayat Abu Daud dari Abu Hurairah secara marfu', Barangsiapa meminta jabatan untuk mengadili kaum Muslimin hingga mendapatkan kemudian keadilannya mengalahkan kecurangannya maka baginya surga. Tetapi barangsiapa yang kecurangannya mengalahkan keadilannya maka baginya neraka. Suatu jabatan tidak akan luput dari kesulitan. Barangsiapa tidak mendapatkan pertolongan dari Allah, maka dia mendapat kesulitan dalam pekerjaannya dan merugi dunia akhirat. Orang yang berakal sehat tentu tidak akan mau memintanya. Bahkan bila dia memiliki kemampuan lalu diberi jabatan tanpa meminta maka dia dijanjikan akan mendapatkan pertolongan.

Jadi, dalam penyelenggaraan pemerintahan terdapat orang yang bekerja berdasarkan tugas dan tanggungjawab dalam jabatan pemerintahan, pengadilan, keuangan, dan lainnya. Suatu jabatan tidak akan luput dari kesulitan, jabatan merupakan amanah (titipan Allah, mengambil dengan hak, menunaikan tanggungjawab padanya, dan tidak boleh tersia-sia) yang diberikan kepada orang yang memiliki kemampuan; meminta jabatan adalah makruh (tidak disukai) karena akan dibuat susah; sedangkan bila diberi jabatan akan ditolong untuk melaksanakannya.

\section{Ambisi Jabatan Yang Tidak Disukai}

Dari Abu Musa RA, dia berkata, aku pernah masuk menemui Nabi SAW bersama dua laki-laki dari kaumku. Salah satu dari keduanya berkata, 'Berilah kami jabatan wahai Rasulullah', lalu yang satunya lagi mengatakan seperti itu. Maka beliau bersabda, 'Sesungguhnya kami tidak memberikan jabatan kepada orang yang memintanya dan tidak pula orang yang berambisi mendapatkannya.' Dan An-Nawawi berkata, "Ini adalah dasar yang mulia tentang menjauhi jabatan terutama bagi mereka yang memiliki kelemahan. Bagi orang yang masuk dalam lingkup tersebut tanpa ada kelayakan untuk menjabatnya dan tidak adil maka dia akan menyesal atas hal yang dilalaikannya ketika dibalas dengan kehinaan pada hari Kiamat. Mereka yang layak dan adil akan mendapatkan pahala yang sangat besar seperti yang diindikasikan oleh berbagai riwayat. Hanya saja masuk ke dalamnya beresiko sangat besar. Oleh karena itu, orang-orang terkemuka menahan diri untuk masuk ke dalam wilayah kekuasaan." (Ibnu Hajar, 2012).

Menurut Al-Asqalani (2012), mendapatkan jabatan dengan meminta ataupun tidak, bahkan dengan 'ambisi' menjadi isyarat bahwa orang yang memegang jabatan dikhawatirkan akan tersia-siakan, posisinya sama dengan orang diberi tanpa meminta, karena umumnya tidak berambisi. Namun, ambisi ini bisa saja ditolerir oleh seseorang yang harus memangku jabatan, karena saat itu menjadi kewajiban bagi dirinya. Memangku jabatan peradilan bagi imam (pemimpin) adalah fardhu ain. Tetapi bagi seorang qadhi, ia fardhu kifayah bila didapatkan orang lain yang juga layak memangku jabatan tersebut.

Jadi, dalam penyelenggaraan pemerintahan dapat dijumpai mereka yang berlomba mendapatkan jabatan, dengan cara meminta atau ambisinya. Selain itu, ada pula orang yang tidak meminta jabatan yaitu orang yang diberi jabatan tanpa meminta, dan tidak berambisi. Harus diperhatikan, jabatan adalah amanah. Pemangku jabatan sebagai pemimpin akan dimintai pertanggungjawaban. Orang yang minta jabatan tanpa kelayakan, tidak adil, akan menyesal mendapatkan kehinaan, sedangkan orang yang layak dan adil maka akan mendapatkan pahala. 


\section{Orang Yang Diberi Jabatan Tidak Menggunakan Sebagaimana Mestinya}

Rasulullah SAW bersabda, "Tidaklah seorang hamba diberi Allah suatu jabatan lalu tidak meliputinya dengan nasehat (tidak menggunakan dengan benar) maka dia tidak akan mencium aroma surga'." Dan Rasulullah SAW bersabda, 'Tidak ada seorang wali yang mengurusi suatu rakyat dari kaum muslimin, lalu dia meninggal dalam keadaan menipu rakyatnya, maka Allah mengharamkan surga baginya".

Keterangan hadits menurut Al-Asqalani (2012), Ibnu Baththal berkata, ini adalah ancaman keras terhadap para pemimpin zalim yang menyia-nyiakan amanah yang dititipkan Allah kepada mereka, atau mengkhianati rakyat, atau menzalimi mereka, sehingga dia dituntut karena menzalimi para hamba pada hari Kiamat. Bagaimana dia mampu berlepas dari kezaliman umat yang demikian banyak. Makna Allah mengharamkan surga atasnya, Allah melaksanakan ancaman atasnya dan orang zalim tidak diredhai. Jadi, orang yang diberi jabatan pimpinan tidak menggunakan semestinya, maka ia akan dimintai pertanggungjawaban atas yang dipimpinnya. Oleh karena itu, pemimpin yang menyia-nyiakan amanah, menghianati rakyatnya adalah pemimpin zalim.

\section{Kapan Seseorang Wajib Memegang Jabatan Qadhi}

Al Hasan berkata, "Allah mengambil perjanjian atas para hakim agar tidak mengikuti hawa nafsu dan tidak takut pada manusia, 'Janganlah kamu menukar ayat-ayat-Ku dengan harga yang murah' (Qs. Al Maa'idah [5]: 440. Kemudian dia membaca, "Wahai Daud, sesungguhnya Kami telah menjadikanmu khalifah (penguasa) di muka bumi, maka berilah keputusan (perkara) di antara manusia dengan adil dan janganlah kamu mengikuti hawa nafsu, karena ia akan menyesatkanmu dari jalan Allah. Sesungguhnya orang-orang yang sesat dari jalan Allah, akan mendapatkan adzab yang berat karena mereka melupakan hari perhitungan. "(Qs. Shaad [38]: 26).

Dan Muzahim bin Zufat berkata, Umar bin Abdul Azin berkata kepada kami, lima perkara, apabila seorang Qadhi tidak memiliki salah satunya maka itu menjadi cacat baginya, yaitu memiliki pemahaman, santun, menjaga kehormatan diri, tegar, serta berilmu dan senantiasa bertanya tentang ilmu. (Al-Asqalani, 2012: 502). Kata hakim, khalifah, dan qadhi tersebut di atas, dapat dijelaskan bahwa menurut Al-Asqalani (2012) kata Hakim digunakan dengan arti Khalifah dan Qadhi.

Keterangan hadits menurut Al-Asqalani (2012), kapan seseorang berhak menjadi Qadhi. Umar bin Abdul Aziz berkata, 5 (lima) perkara apabila Qadhi tidak memiliki salah satunya cacat. Hendaknya dia paham. Santun, maksudnya memberi maaf orang yang menyakitinya dan tidak terburu-buru menuntut balas. Menjaga kehormatan diri, maksudnya tidak terjerumus dalam perbuatan haram, karena jika dia berilmu dan tidak menjaga kehormatannya maka bahaya yang ditimbulkan lebih besar daripada yang dilakukan oleh orang bodoh.

Berikutnya, tegar, maksudnya kuat dan tegas dalam kebenaran, tidak menuruti hawa nafsu. Mengambil hak seseorang dari pelaku kebatilan tanpa merasa sungkan. Berilmu dan senantiasa bertanya tentang ilmu, maksudnya di samping ilmu yang dimilikinya dia juga senantiasa berdiskusi tentang ilmu dengan orang lain, karena bisa saja dia mendapatkan dari orang lain ilmu yang lebih kuat dari yang diketahuinya. Jika tidak ada orang yang terkumpul sifat itu dalam dirinya, maka wajib dicari orang yang lebih sempurna dan utama di antara mereka. 
Diterangkan pula, kriteria syarat pemegang jabatan Qadhi yaitu adil, jujur, tegar, santun, menjaga kehormatan diri (jauh dari menuruti hawa nafsu, senantiasa memelihara lisan, perut, dan kemaluannya), dan berilmu (menanyakan dan menelaah ilmu), bermusyawarah dengan ulama dengan penuh hormat, wara' (akan membuat berhati-hati), cerdik dan cerdas (memahami perkataan orang bersengketa, akan menjadikan bisa bertanya). Pengetahuan yang harus dimiliki dalam tugasnya, pandai tentang Al-Qur'an, Sunnah dan menghapal hadits, mengetahui perkataan sahabat, mengerti masalah yang disepakati dan diperselisihkan ahli fikih, tahu masalah riwayat yang shahih dan lemah. Jika sifat itu tidak terkumpul maka yang wajib dicari orang lebih utama di antara mereka.

Selanjutnya, diterangkan metode yang digunakan oleh hakim atau qadhi dalam mengambil keputusan yaitu mengetahui hukum dan mencari solusi masalah dari Al-Qur'an; bila tidak menemukannya dicari Sunnah, bila tidak ada maka mempraktekkan apa yang disepakati sahabat, dan bila mereka berselisih dalam masalah itu maka dicari apa yang dia dapati lebih dekat kepada Al-Qur'an, Sunnah, kemudian fatwa sahabat. Jadi, kewajiban memegang jabatan hakim atau qadhi, setelah seseorang memenuhi kriteria adil, jujur, tegar, berilmu dan bermusyawarah. Dan menguasai metode kerja dalam mengambil keputusan berdasarkan Al-Qur'an, Sunnah, dan fatwa sahabat.

\section{Orang Kepercayaan Pemimpin Atau Imam Dan Anggota Musyawarahnya}

Al-Muhibb Ath-Thabari berkata, "Kata bithaanah artinya para pembantu dan orangorang pilihan. Jadi, Bithaanah (pembantu dekat) adalah orang-orang yang leluasa masuk menemui pemimpin atau imam. Maksudnya orang yang diajak musyawarah dalam mencari solusi untuk memecahkan berbagai urusan masyarakat.

Menurut Al-Asqalani (2012) terdapat beberapa pendapat mengenai pembantu dekat: (1) Ibnu At-Tin menukil dari Asyhab bahwa dia berkata, seorang hakim patut mengambil orang yang melaporkan urusan manusia kepadanya secara rahasia. Akan tetapi orang itu sebaiknya terpercaya, amanah, cerdas, dan pandai. Karena musibah hanya akan masuk menimpa hakim yang amanah yang menerima perkataan orang tidak bisa terpercaya. Apabila hakim berbaik sangka terhadap orang itu, maka dia wajib mengecek kebenaran laporannya. Semakna dengan hadits Aisyah yang diriwayatkan secara marfu', barangsiapa diantara kamu memegang sesuatu pekerjaan, lalu Allah menginginkan kebaikan baginya, maka dijadikan untuknya pembantu yang baik, jika dia lupa maka diingatkannya, dan jika dia ingat maka dibantunya.

Selanjutnya, (2) Ibnu At-Tin berkata, mungkin maksud 'dua orang kepercayaan' adalah dua menteri atau asisten. Tetapi mungkin juga maksudnya malaikat dan syetan; dan (3) AlKarmani berkata, mungkin maksudnya adalah jiwa yang memerintah kepada keburukan dan jiwa yang mendorong kepada kebaikan, karena masing-masing dari keduanya memiliki kekuatan malaikat dan kekuatan syetan. Namun, bisa saja memahaminya dengan semua makna yang disebutkan tadi. Artinya, setiap jenis pembantu itu terdapat pada diri individu tertentu. Jadi, pemimpin dalam menyelenggarakan pemerintahan dibantu oleh orang-orang kepercayaan sebagai anggota musyawarahnya, mereka antara lain menteri dan hakim dan pegawai yang membantunya yaitu asisten atau ajudan. 


\section{Pemuka-Pemuka Bagi Manusia}

Rasulullah bersabda, "Sungguh aku tidak tahu siapa yang mengizinkan di antara kamu dan siapa yang tidak mengizinkan. Kembalilah hingga pemuka-pemuka kamu mengajukan urusan kamu kepada kami." Keterangan hadits menurut Al-Asqalani (2012), pemuka bagi manusia, maksudnya adalah orang yang memegang urusan sebagian manusia. Contohnya araftu alal qaum artinya aku mengurusi kaum itu. Disebut ariif (orang yang tahu) karena mengetahui urusan-urusan manusia sehingga dia dapat melaporkan keadaan mereka kepada para pemimpin jika dibutuhkan. Sebagian lainnya mengatakan ariif posisinya berada di bawah daripada pemimpin pemerintahan.

Ibnu Bathal berkata, dalam hadits ini terdapat pensyariatan mengangkat 'pemukapemuka', karena pemimpin tertinggi tidak mungkin terlibat langsung dalam semua urusan manusia, sehingga dia butuh mengangkat orang-orang yang membantu tugas-tugasnya. Perintah dan larangan bila disampaikan langsung kepada semua manusia, maka terkadang sebagian mereka tidak dapat memahaminya dengan baik, sehingga perintah atau larangan itu tidak dilaksanakan. Tetapi bila setiap kaum diangkat seseorang menjadi pemukanya, maka tidak ada pilihan bagi mereka kecuali melaksanakan apa yang diperintahkan.

Menurut Al-Asqalani (2012), penafsiran ini dikuatkan hadits lain yang mengancam para pemimpin sebagaimana ancaman yang diberikan kepada para pemuka. Hal ini menunjukkan bahwa yang dimaksud dengannya adalah isyarat, setiap yang menduduki jabatan tersebut tidaklah aman, dan semuanya berada dalam bahaya. Namun tetap saja ada yang dikecualikan dari bahaya itu. Kalimat 'al arafah adalah $h a q$ ', artinya pada dasarnya jabatan sebagai pemuka adalah haq (benar) karena kemaslahatan manusia mengharuskan adanya jabatan itu, dimana pemimpin tertinggi memerlukan orang yang membantunya, untuk melaksanakan tugas yang diembannya.

Jadi, dalam penyelenggaraan pemerintahan terdapat pemuka-pemuka (ariif) yang memegang urusan sebagian manusia, posisinya berada di bawah pemimpin pemerintahan, dalam setiap kaum (masyarakat) dapat diangkat seorang pemuka yang mengetahui urusan kaumnya, sehingga dia dapat melaporkan keadaan kaumnya kepada pemimpin jika dibutuhkan, dasarnya jabatan sebagai pemuka adalah haq karena kemaslahatan manusia mengharuskan adanya jabatan itu, dan pemimpin tertinggi memerlukan pemuka yang membantunya untuk melaksanakan tugasnya. Sebagai pemimpin kaumnya maka pemuka (masyarakat) akan dimintai pertanggungjawaban atas yang dipimpinnya.

\section{Perintah Wali Untuk Dituruti Dan Tidak Saling Bertentangan}

Dari Sa'id bin Abi Burdah, dia berkata: Aku mendengar bapakku berkata: Nabi SAW pernah mengutus bapakku - yakni Abu Musa - dan Mu'adz bin Jabal ke Yaman, maka beliau bersabda, "Hendaklah kalian berdua memberi kemudahan dan tidak mempersulit, berilah berita gembira dan tidak membuat orang lari, dan hendaklah kalian berdua saling mendukung."

Keterangan hadits menurut Al-Asqalani (2012), saling menuruti maksudnya saling mendukung dalam suatu keputusan, jangan berselisih, karena sikap seperti itu hanya akan berujung pada perselisihan orang-orang yang mengikuti keduanya. Akibatnya, akan timbul permusuhan dan berlanjut dengan saling memerangi. Pedoman saat terjadi perbedaan adalah firman Allah dalam surah An-Nisaa' ayat 59, Apabila kamu berselisih tentang sesuatu maka kembalikanlah ia kepada Allah [Al-Qur'an dan Rasul [Sunnahnya]). 
Menurut Al-Asqalani (2012), dasar yang menjadi pegangan adalah wilayah kerja Mu'adz adalah An-Najud dan dataran tinggi wilayah Yaman. Sedangkan wilayah kerja Abu Musa adalah At-Taha'im serta dataran rendahnya. Atas dasar ini, maka diperintahkan agar mereka berdua saling bekerjasama dan tidak berselisih paham untuk perkara-perkara yang membutuhkan keduanya berkumpul ketika memutuskan suatu perkara. Ketika mereka berdua bekerjasama, lalu sepakat atas suatu hukum maka itulah yang diinginkan, tetapi bila belum menemukan kata sepakat maka mereka sebaiknya diam hingga diambil keputusan yang tepat, atau mereka mengajukan persoalan itu kepada pejabat di atas mereka.

Pelajaran yang dapat diambil menurut Al-Asqalani (2012), perintah untuk memudahkan urusan, berlaku lembut kepada rakyat, menjadikan keimanan dicintai oleh mereka, tidak berlaku keras yang berakibat hati rakyat tidak bisa menerima, terutama sekali mereka yang baru saja masuk Islam, atau orang mendekati masa taklif diantara anak-anak, agar keimanan menancap lebih dahulu dalam hati dan mereka terbiasa atasnya.

Jadi, pimpinan dalam menyelenggarakan pemerintahan menerapkan prinsip-prinsip administrasi: (1) pengarahan (commanding), seperti halnya perintah wali ketika mengarahkan dua orang pejabatnya ke suatu tempat agar saling menuruti dan tidak bertentangan, diperintahkan agar mereka berdua saling bekerjasama dan tidak berselisih paham untuk perkara yang membutuhkan keduanya berkumpul ketika memutuskan suatu perkara. (2) Koordinasi (coordinating) kerjasama dengan kolega. Ketika mereka berdua bekerjasama, lalu sepakat atas suatu hukum maka itulah yang diinginkan, tetapi bila belum menemukan kata sepakat maka mereka sebaiknya diam hingga diambil keputusan yang tepat, atau mereka mengajukan persoalan itu kepada pejabat di atasnya; dan (3) Pelaporan (reporting) yaitu mengajukan persoalan kepada pejabat atasannya untuk diambil keputusan.

\section{Nabi Muhammad SAW Tidak Memiliki Penjaga Pintu}

Hadits Anas tentang kisah perempuan yang datang meminta maaf atas perkataannya, (menyingkirlah dariku) ketika Nabi mendapatinya sedang menangis di sisi kubur lalu memerintahkannya untuk bersabar. Dalam hadits ini disebutkan juga (Dia datang ke pintu rumahnya dan tidak menemukan padanya penjaga pintu). Al-Karmani berkata, makna perkataan, 'Tidak menemukan penjaga pintu', adalah dia tidak memiliki penjaga pintu yang tetap, atau di kamar yang menjadi tempat beliau, atau penjaga pintu itu bukan atas penunjukan beliau, bahkan itu muncul dari inisiatif Abu Musa dan Rabah. Menurut Al-Asqalani (2012), bila tidak ada penjaga pintu di kamar sementara ia merupakan tempat bagi orang yang tidak mau diganggu, maka tentu di tempat lain lebih patut lagi tidak mengambil penjaga pintu.

Menurut Al-Asqalani (2012), para ulama berbeda pendapat tentang persyariatan mengambil ajudan bagi para hakim: (1) Asy-Syafi'i dan sejumlah ulama berkata, tidak patut bagi hakim untuk mengambil ajudan; (2) sekelompok ulama membolehkannya. Mereka mengatakan, hakim tidak patut mengambil ajudan dalam kondisi stabil dan orang dalam kondisi baik serta menaati hakim; dan (3) sebagian lagi berkata, hakim dianjurkan mengambil ajudan agar bisa menertibkan orang yang berperkara, mencegah orang melampaui batas, dan menahan tindakan orang yang jahat.

Selain itu, Al-Asqalani berpendapat (2012), tugas penjaga pintu (ajudan) adalah memberitahukan kepada hakim keadaan orang yang datang, terutama tujuannya. Bisa saja seorang hendak mengadukan perkara namun dikira oleh hakim sebagai tamu biasa yang tidak boleh diperlakukan seperti orang berperkara. Hakim tidak dianjurkan menggunakan ajudan untuk menghalangi dirinya dengan masyarakat. Rasulullah bersabda, "Barangsiapa diberi 
kekuasaan oleh Allah memegang urusan manusia, lalu dia membuat batas atau penghalang untuk memenuhi kebutuhan mereka, maka Allah akan membuat batas atau penghalang dari kebutuhannya pada hari Kiamat."

Dalam hadits ini terdapat ancaman keras bagi hakim yang membuat batas antara dirinya dengan masyarakat tanpa $u d z u r$ yang jelas, karena perbuatan ini bisa menunda sampainya hak kepada pemiliknya atau bahkan menyia-nyiakan. Oleh karena itu, siapa saja yang ingin mengambil penjaga pintu (ajudan) maka orang tersebut sebaiknya dapat dipercaya, menjaga kehormatan diri, jujur, bijak, bagus akhlaknya, dan mengetahui keadaan masyarakat.

Jadi, dalam penyelenggaraan pemerintahan terdapat jabatan penjaga pintu atau ajudan daripada hakim atau qadhi. Tidak semua hakim boleh mengambil penjaga pintu, tanpa memenuhi kriteria yang telah ditentukan. Tugas ajudan seperti penjaga pintu memberitahukan keadaan orang yang datang, tujuannya, menyampaikan berita sesuatu masalah kepada hakim. Termasuk, membantu hakim menertibkan orang yang berperkara.

\section{Anjuran Memilih Juru Tulis Yang Amanah Dan Cerdas}

Zaid berkata: Abu Bakar berkata, "Sungguh engkau adalah laki-laki yang masih muda serta cerdas dan kami tidak mencurigaimu. Dahulu engkau biasa menulis wahyu untuk Rasulullah SAW, maka telusurilah Al-Qur'an dan kumpulkan'. Keterangan hadits menurut AlAsqalani (2012), anjuran memilih juru tulis yang amanah dan cerdas maksudnya juru tulis (notulen) keputusan sidang dan lainnya. Imam Bukhari menyebutkan hadits Zaid bin Tsabit tentang kisahnya bersama Abu Bakar dan Umar yang berkaitan dengan upaya mengumpulkan Al-Qur'an.

Sesungguhnya Nabi SAW mengangkat Abdullah bin Arqam sebagai juru tulis. Maka dia menuliskan surat-surat untuk Nabi SAW kepada para raja. Sifat amanahnya di sisi Nabi SAW mencapai tingkat dimana beliau memerintahkannya menulis dan memberi cap tanpa membacanya kembali. Kemudian beliau mengangkat Zaid bin Tsabit sebagai juru tulis. Dia kemudian menuliskan wahyu dan menulis surat-surat kepada raja. Apabila keduanya tidak ada maka yang menjadi juru tulis beliau adalah Ja'far bin Abi Thalib. Terkadang pula sejumlah sahabat menuliskan untuk beliau. Jadi, dalam penyelenggaraan pemerintahan terdapat jabatan juru tulis (notulen) keputusan sidang dan lainnya yang dipilih dengan kriteria amanah dan cerdas.

\section{Penerjemah Untuk Hakim, Dan Apakah Dibolehkan Satu Orang Penerjemah}

Dari Zaid bin Tsabit, bahwa Nabi SAW memerintahkannya untuk mempelajari tulisan Yahudi, hingga aku menulis untuk Nabi SAW surat-suratnya, lalu aku membacakan surat-surat mereka ketika mereka menulis kepadanya. Keterangan hadits menurut Al-Asqalani (2012) tentang (berapa) penerjemah untuk (membantu) hakim: (1) Umar berkata saat di sisinya ada Ali Abdurrahman dan Utsman, apa yang dikatakan orang ini? Abdurrahman bin Hathib berkata, Aku berkata, 'Dia mengabarkan kepadaku tentang sahabatnya yang melakukan hal ini terhadapnya'. Abu Hamzah berkata, Aku pernah menerjemahkan antara Ibnu Abbas dengan orang-orang. Sebagian orang berkata, hakim harus memiliki dua orang penerjemah.

Kemudian, (2) Imam Bukhari ingin mengisyaratkan, apakah cukup satu orang penerjemah atau tidak? Menurut Abu Hanifah, cukup satu orang penerjemah. Ini juga salah satu riwayat dari Imam Ahmad dan dipilih oleh Imam Bukhari serta sekelompok ulama; (3) Imam Asy-Syafi'i -dan riwayat lain yang lebih kuat dari imam Ahmad- mengatakan, apabila 
hakim tidak mengetahui bahasa orang yang berperkara, maka hakim tidak boleh menerima hal itu kecuali dua orang yang adil, karena dia menukil apa yang tersembunyi bagi hakim dalam perkara yang berhubungan dengan hukum. Sehingga disyaratkan sifat adil seperti dalam kesaksian.

Selanjutnya, (4) Al-Karabisi menyebutkan, Khulafa' Rasyidin dan para raja sesudah mereka hanya memiliki satu orang penerjemah. Ibnu At-tin menukil dari Ibnu Abdul Hakam, hanya satu orang merdeka dan adil yang boleh menjadi penerjemah. Apabila seorang penerjemah mengakui sesuatu, maka saya sukai bila hal itu didengar darinya oleh dua orang saksi, lalu keduanya mengajukannya ke hadapan hakim. Jadi, dalam penyelenggaraan pemerintahan dibutuhkan pegawai yang mempunyai kemampuan dan keterampilan sebagai tenaga penerjemah yang membantu hakim dalam pengambilan keputusan.

\section{Gaji Hakim Dan Pegawai}

Gaji hakim atau qadhi dan para pegawainya. Seorang qadhi menurut hukum syariat akan berkecukupan, karena kebutuhannya akan dipenuhi dari baitul mal (kas Negara). Namun, jika tidak diberi tunjangan dari baitul mal sementara dia butuh maka mengangkat orang kaya lebih utama daripada mengangkat orang miskin sebab sangat rawan melakukan hal yang tidak diperbolehkan. Al-Asqalani (2012) menyatakan, tidak mendapati masa dimana orang secara terang-terangan meminta jabatan qadhi dengan alasan memenuhi kebutuhan hidupnya, padahal dia tahu tidak ada tunjangan bagi jabatan qadhi yang diambil dari baitul mal.

Syuraih Al-Qadhi pernah mengambil upah atas jabatannya sebagai qadhi. Aisyah berkata, bahwa pemegang wasiat makan sesuai gaji pekerjaannya. Abu Bakar dan Umar juga makan (gaji jabatan). Nabi SAW bersabda, "Ambillah dan jadikanlah sebagai hartamu lalu sedekahkan. Selama harta yang diberikan kepadamu sedang engkau tidak mendambakan dan tidak memintanya maka ambillah, dan apa yang tidak (diberikan kepadamu) maka janganlah engkau mengharapkannya" (Al-Asqalani, 2012).

Keterangan hadits menurut Al-Asqalani (2012), maksud gaji disini adalah materi yang dikeluarkan pemerintah setiap bulan dari baitul mal untuk yang berhak. Sedangkan yang dimaksud dengan pemberian adalah materi yang dikeluarkan setiap tahun." Mungkin juga maksud perkataan, "para pegawainya" dikaitkan dengan kata 'hakim', adalah gaji orang yang membantu hakim dalam melaksanakan tugas pemerintahan.

Menurut At-Thabari, mayoritas ulama berpendapat bahwa seorang qadhi boleh mengambil upah atas tugas jabatan yang diembannya karena tugas itu dapat menyibukkannya sehingga tidak sempat mencari nafkah untuk dirinya. Hanya saja sekelompok ulama salaf tidak menyukai hal seperti itu, namun juga tidak mengharamkannya. Jadi, dalam penyelenggaraan pemerintahan diadakan gaji pegawai. Gaji adalah materi yang dikeluarkan pemerintah setiap bulan dari baitul mal untuk yang berhak diantaranya hakim atau qadhi dan orang-orang yang membantu dalam melaksanakan tugas pemerintahan.

\section{Pujian Dan Sanjungan Kepada Penguasa Yang Tidak Disukai, Dan Ketika Keluar Mengatakan Hal Yang Berbeda}

Dari Ashim bin Muhammad bin Zaid bin Abdullah bin Umar, dari bapaknya, dia berkata: Beberapa orang berkata kepada Ibnu Umar, sesungguhnya kami pernah datang menemui penguasa kami dan mengatakan kepada mereka hal yang berbeda dengan apa yang kami katakan ketika keluar dari sisi mereka. Dia berkata, kami dahulu menganggapnya sebagai 
kemunafikan. Dari Abu Hurairah, bahwa dia mendengar Rasulullah bersabda, "Sesungguhnya seburuk-buruk manusia adalah pemilik dua muka, yaitu orang yang datang kepada mereka dengan satu muka, dan datang kepada mereka dengan muka yang lain”.

Keterangan hadits menurut Al-Asqalani (2012), Al Khara'ithi menyebutkan dalam kitab Al Masawi melalui Asy-sya'bi, Aku pernah berkata kepada Ibnu Umar, Sungguh kami pernah masuk menemui pemimpin-pemimpin kami dan memuji mereka. Apabila kami keluar maka kami mengatakan untuk mereka apa yang berbeda dengan itu. Dia berkata, kami dahulu menganggap hal ini di masa Rasulullah SAW sebagai kemunafikan. Jadi, dalam penyelenggaraan pemerintahan dapat dijumpai ada orang yang memuji atau menyanjung pemimpinnya ketika berhadapan dengannya, tetapi mereka mengatakan hal yang berbeda ketika di belakangnya, ini merupakan sifat munafik atau nifak.

\section{Hadiah Pegawai Pemerintahan}

Nabi SAW bersabda, "Apa urusan petugas yang kami utus, dia datang dan berkata, 'Ini untukmu dan ini untukku'. Mengapa dia tidak duduk di rumah bapaknya dan ibunya, lalu diperhatikan apakah dia diberi hadiah atau tidak. Demi Dzat yang jiwaku berada di tanganNya, tidaklah dia datang membawa sesuatu melainkan pada hari Kiamat nanti datang sambil membawa di atas pundaknya, apabila untu maka ia bersuara, apabila sapi maka ia menguak, apabila kambing maka ia mengembik."

Pelajaran yang dapat diambil menurut Al-Asqalani (2012), larangan bagi pegawai pemerintahan menerima hadiah dan orang yang berada dalam bidang kerjanya. Ini berlaku apabila atasannya tidak memberi izin. Berdasarkan apa yang diriwayatkan At-Tirmidzi dari Qais bin Abi Hazim, dari Muadz bin Jabal, dia berkata, Rasulullah SAW mengutusku ke Yaman dan bersabda, "Jangan engkau mengambil sesuatu tanpa izinku, karena sesungguhnya itu adalah khianat." Jadi, dalam penyelenggaraan pemerintahan terdapat larangan menerima hadiah dari orang yang berada dalam bidang kerjanya apabila atasannya tidak memberi izin, disinilah peran pimpinan melakukan pengawasan terhadap pegawai.

Selanjutnya, hasil pengumpulan data tersebut dilakukan pembahasan berdasarkan teknik analisis sintesis maka ditemukan 6 (enam) kategori pemikiran Al-Asqalani dalam ilmu administrasi negara.

\section{Kepemimpinan dalam Pemerintahan}

Pemimpin dalam pemerintahan memiliki tanggungjawab, sebagai berikut: (1) Kepemimpinan penguasa tertinggi adalah menjaga syariat dengan menegakkan hukum serta berlaku adil dalam menetapkan hukum dan akan dimintai pertanggungjawaban; dan (2) Kepemimpinan pembantu termasuk pegawai yang membantu pimpinan. Orang kepercayaan imam (pemimpin) dan anggota musyawarahnya sebagai pembantu pimpinan dalam penyelenggaraan pemerintahan, antara lain menteri dan hakim yang juga dibantu oleh asisten/ajudannya. Mereka harus memelihara apa yang dalam tanggungjawabnya serta melakukan apa yang dapat mendatangkan kebaikan padanya.

Selanjutnya, (3) Pemuka-pemuka bagi manusia atau ariif adalah mereka yang memegang urusan sebagian manusia. Sebagai pembantu pemimpin pemerintahan mereka posisinya berada di bawah pemimpin pemerintahan, dalam setiap kaum (masyarakat) dapat diangkat seorang pemuka (masyarakat) yang mengetahui urusan kaumnya, sehingga dia dapat melaporkan keadaan kaumnya kepada pemimpin jika dibutuhkan. Dasarnya jabatan sebagai 
pemuka adalah haq karena kemaslahatan manusia mengharuskan adanya jabatan itu. Mereka yang menjabat sebagai pemimpin akan dimintai pertanggungjawaban atas yang dipimpinnya.

Di pihak lain, ada perintah mendengar dan taat kepada pemimpin atau imam selama tidak dalam kemaksiatan. Perintah tersebut berlaku dalam hal yang disukai dan tidak disukai, apabila menyuruh kemaksiatan maka tidak boleh didengar dan diikuti. Jadi, pemimpin tersebut akan dimintai pertanggungjawaban atas yang dipimpinnya. Jika ada pemimpin menyuruh kemaksiatan maka tidak boleh didengar dan diikuti; dan jika suka mempersulit urusan sehingga menyusahkan rakyatnya maka Allah akan mempersulit pemimpin itu, sebagai balasan yang sepadan dengan perbuatannya.

\section{Jabatan dalam Pemerintahan}

Al-Asqalani menjelaskan orang-orang yang bekerja berdasarkan tugas dan tanggungjawabnya dalam jabatan pemerintahan. Misalnya, di bidang pengadilan, keuangan, dan lainnya. Jabatan adalah amanah yang diberikan kepada orang yang memiliki kemampuan. Diantara mereka ada yang berlomba-lomba mendapatkan jabatan pemerintahan, dengan cara meminta atau dengan ambisinya. Meminta jabatan adalah makruh karena akan dibuat susah; begitu pula ambisi jabatan tidak disukai. Selain itu, ada orang yang tidak meminta jabatan yaitu orang yang diberi jabatan tanpa meminta, dan tidak berambisi. Mereka akan ditolong untuk melaksanakannya.

Semua orang yang memangku jabatan pemimpin akan dimintai pertanggungjawaban, orang yang meminta jabatan tanpa ada kelayakan, tidak berbuat adil, maka akan menyesal mendapatkan kehinaan, sedangkan orang yang layak dan adil maka akan mendapatkan pahala. Orang yang diberi jabatan pimpinan tidak menggunakan sebagaimana mestinya, yaitu tidak sesuai dengan ketentuan tugas dan tanggungjawabnya maka ia akan dimintai pertanggungjawaban atas yang dipimpinnya. Selanjutnya, pemimpin yang menyia-nyiakan amanah, tidak menggunakan jabatan sesuai dengan tugas dan tanggungjawabnya, menghianati atau menipu rakyatnya adalah pemimpin zhalim.

Ambisi jabatan bisa ditolelir oleh seseorang yang harus memangku jabatan, karena saat itu menjadi kewajiban bagi dirinya. Memangku jabatan peradilan bagi imam (pemimpin) adalah fardhu ain. Tetapi bagi seorang qadhi, ia hanyalah fardhu kifayah bila didapatkan orang lain yang juga layak memangku jabatan tersebut. Jadi, konsep pemikiran Al-Asqalani dalam ilmu administrasi negara bersumber dari al-Qur'an dan hadits, menjelaskan jabatan adalah amanah, dan mereka yang memegang jabatan sebagai pemimpin akan dimintai pertanggungjawaban atas yang dipimpinnya.

\section{Kepegawaian dalam Organisasi Pemerintahan}

Konsep pemikiran Al-Asqalani mengenai kepegawaian dalam organisasi pemerintahan, sebagai berikut: (1) Orang kepercayaan pemimpin dan anggota musyawarahnya antara lain menteri, hakim (qadhi); (2) Penjaga pintu atau ajudan daripada hakim atau qadhi. Tugas ajudan seperti tugas penjaga pintu yaitu memberitahukan keadaan orang yang datang, menyampaikan berita sesuatu masalah kepada hakim, membantu menertibkan orang berperkara, mencegah orang melampaui batas, dan menahan tindakan orang jahat.

Selanjutnya, (3) Juru tulis, dibutuhkan notulen keputusan sidang dan lainnya. Kriteria memilih juru tulis adalah amanah dan cerdas; dan (4) Penerjemah, dibutuhkan yang mempunyai keterampilan terjemahan yang membantu hakim dalam pengambilan keputusan. 
Jadi, konsep pemikiran Al-Asqalani dalam ilmu administrasi negara mengenai kepegawaian dalam organisasi pemerintahan meliputi jabatan hakim atau qadhi, penjaga pintu atau ajudan, juru tulis dan tenaga penerjemah.

\section{Prinsip-Prinsip Administrasi}

Pimpinan menerapkan prinsip-prinsip administrasi untuk mencapai tujuan organisasi dengan baik. Konsep pemikiran Al-Asqalani yang mempunyai relevansi dengan prinsip-prinsip administrasi, yaitu: (1) Pimpinan menerapkan prinsip pengarahan (commanding), sebagaimana dijelaskan tentang perintah wali ketika mengarahkan dua orang pejabatnya ke suatu tempat agar saling menuruti dan tidak bertentangan, diperintahkan agar mereka bekerjasama dan tidak berselisih paham untuk perkara yang membutuhkan keduanya berkumpul memutuskan suatu perkara; (2) Pimpinan melakukan fungsi koordinasi (coordinating) yaitu kerjasama dengan kolega. Ketika bekerjasama, sepakat atas suatu hukum maka itulah yang diinginkan, tetapi bila belum sepakat maka mereka sebaiknya diam hingga diambil keputusan yang tepat, atau mereka mengajukan persoalan itu kepada pejabat di atasnya.

Selanjutnya, (3) Dalam hal ini melakukan fungsi pelaporan (reporting) yaitu mengajukan persoalan kepada pejabat atasannya untuk diambil keputusan; dan (4) Pimpinan menjalankan fungsi pengawasan (controlling) yang dilakukan melalui pemeriksaan (auditing) terhadap pegawai yang membantunya. Jadi, konsep pemikiran Al-Asqalani dalam ilmu administrasi negara mengenai prinsip-prinsip administrasi meliputi pengarahan (commanding); pengkoordinasian (coordinating); pemeriksaan (auditing) atau pengawasan (controlling); dan pelaporan (reporting).

\section{Penggajian}

Konsep pemikiran Al-Asqalani tentang penggajian, dapat ditelusuri dari penjelasannya tentang gaji hakim dan para pegawainya. Pegawai dalam melaksanakan tugas pemerintahan diberikan gaji. Gaji adalah materi yang dikeluarkan oleh setiap bulan dari baitul mal untuk yang berhak diantaranya hakim atau qadhi dan orang-orang yang membantu penyelenggaraan tugas pemerintahan. Jadi, konsep pemikiran Al-Asqalani mengenai gaji adalah materi yang dikeluarkan pemerintah setiap bulan dari baitul mal diberikan untuk yang berhak dalam melaksanakan tugas pemerintahan.

\section{Penghargaan dan Sanksi}

Konsep pemikiran Al-Asqalani mengenai penghargaan dan sanksi atau reward and punishment, yaitu: (1) Penghargaan dalam bentuk pujian. Dijelaskan pujian atau sanjungan kepada penguasa yang tidak disukai, karena ketika keluar mengatakan yang berbeda, ini merupakan sifat munafik atau nifak; (2) Penghargaan juga dapat dijumpai dalam bentuk pemberian hadiah. Dijelaskan adanya larangan menerima hadiah dari orang yang berada dalam bidang kerjanya apabila atasannya tidak memberi izin.

Alasannya, pemberian hadiah ini berkaitan dengan sogok. Disinilah peran pimpinan melakukan pengawasan (controlling) terhadap pegawai. Jadi, konsep penghargaan dan sanksi meliputi larangan memberi pujian bila tidak benar; dan larangan menerima hadiah dari orang yang berada dalam bidang kerjanya apabila atasannya tidak memberi ijin. Selanjutnya, bila dilanggarnya maka pimpinan dapat memberikan sanksi. 
Dengan demikian, konsep pemikiran Al-Asqalani dalam ilmu administrasi Negara, meliputi kategori-kategori: (1) Kepemimpinan, (2) Jabatan dalam pemerintahan, (3) Kepegawaian dalam Organisasi Pemerintahan; (4) Prinsip-prinsip administrasi; (5) Penggajian; dan (6) Penghargaan dan Sanksi. Konsep pemikiran Al-Asqalani tersebut bersumber kepada al-Qur'an, Hadits dan khasanah Islam.

Hal tersebut menunjukkan eksistensi keilmiahan dan ketokohan Al-Asqalani; dan sumbangannya kepada dunia ilmu pengetahuan berupa konsep-konsep dan dasar-dasar penyelenggaraan hukum dan penyelenggaraan kekuasaan pemerintahan yang baik berdasarkan al-Qur'an, Hadits dan khasanah Islam yang mempunyai hubungan relevansi dengan konsep disiplin ilmu administrasi negara masa kini.

\section{Simpulan}

Konsep pemikiran Ibnu Hajar Al-Asqalani dalam ilmu administrasi negara ada 6 (enam) kategori yaitu: Kepemimpinan dalam pemerintahan; Jabatan dalam pemerintahan; Kepegawaian dalam Organisasi Pemerintahan; Prinsip-prinsip administrasi; Penggajian; dan Penghargaan dan Sanksi. Pemikiran tersebut bersumber al-Qur'an, Hadits dan khasanah Islam. Dengan demikian Ibnu Hajar Al-Asqalani telah menunjukkan ketokohannya dalam meletakkan dasar-dasar penyelenggaraan kekuasaan pemerintahan yang baik mempunyai hubungan relevansi dengan konsep ilmu administrasi negara kontemporer.

Pemangku kepentingan dan akademisi di bidang disiplin ilmu administrasi negara, perlu menerapkan konsep pemikiran Ibnu Hajar Al-Asqalani dalam perkuliahan ilmu administrasi negara masa kini; dan mempelajari kembali ilmu pengetahuan yang bersumber dari al-Qur'an dan Hadits serta warisan khasanah Islam dengan tujuan untuk mengembangkan ilmu administrasi negara dengan pendekatan non-Western Perspektif.

\section{Referensi}

Al-Asqalani, I.H. (2012) Fathul Baari: Penjelasan Kitab Shahih Bukhari Buku 35, Penerjemah: Amiruddin, Jakarta: Pustaka Azzam.

Awwaliansyah, I. (2017) Tesis: Pemikiran Pendidikan Ibnu Hajar Al-Asqalani dan Implementasinya, Jakarta: Institut Ilmu Al-Qur'an.

AAPA (2018) Proceedings of the Annual Conference of Asian Association for Public Administration: "Reinventing Public Administration in a Globalized World: A NonWestern Perspective", The Advance in Social Science Education and Humanities Research, Yogyakarta: UGM.

Fauzi, M. (2016) Ilmu Ekonomi: Hukum Makelar menurut tinjauan hadits Ibnu Hajar AlAsqalani (Studi Kitab Fathul Baari), Meulaboh: STAIN Tengku Dirundeng.

Gullick, L., Lyndall U. (1937) Papers on the Science of Administration. New York: Institute of Public Administration, Columbia University.

Juliadarma, M. (2019) Penelitian Konsep Pendidikan Islam dalam Kitab Fathul Baari, elBidayah: Journal of Islamic Elementary Education.

Khaldun, I. (2012) Mukaddimah, penerjemah: Ilham, M., Supar, M., Zuhri, A. Jakarta: Pustaka Al-Kautsar. 
Khotijah, S. (2019) Konsep Pendidikan Jihad Menurut Ibnu Hajar Al-Asqalani dalam kitab Fathul Baari, Lampung: UIN Raden Intan.

Sherwani, H.K. (1964) Mempelajari pendapat sarjana-sarjana Islam tentang Administrasi Negara, penerjemah M. Arief Lubis, Jakarta, Tintamas.

The University of Dhaka () Department of Public Administration. Contribution of Kautilya, Confucius, Ibn Khaldun, and Max Weber on State, Administration, and Governance: relevance and contrast with the modern concepts, Dhaka.

Waldo, D. (1955) The Study of Public Administration, New York: The Country Life Press.

Weber, M. (1947) The Theory of Social and Economic Organisation, edited with an introduction by Talcott Parsons, New York: The Free Press.

Wiryanto, W. (2018) Developing Theories of Non-Western Public Administration Through the Islamization of Public Administration, Proceedings of the 2018 Annual Conference of Asian Association for Public Administration, Yogyakarta: UGM. 